\title{
Trust and strategic change: an organizational justice perspective
}

\author{
Mark NK Saunders \\ School of Management \\ University of Surrey \\ Guildford \\ Surrey GU2 7XH \\ mark.saunders@surrey.ac.uk \\ Tel: 01483-686731 \\ Fax: 01483-686346
}

\section{Brief biographical details}

Mark NK Saunders is Professor in Business Research Methods at the University of Surrey, School of Management. He holds Visiting Professorships at Newcastle Business School, Northumbria University; and Worcester Business School, University of Worcester. His research interests include human resource aspects of the management of change including trust and downsizing, and research methods. He has published in management journals including Personnel Review, European Journal of Work and Organisational Psychology, Service Industries Journal, Employee Relations and International Journal of Public Sector Management. He is a member of the editorial boards of Personnel Review, Journal of Services Research and the Electronic Journal of Business Research. He is co-editor of Organizational Trust: a Cultural Perspective (2010, Cambridge University Press) and lead author of Research Methods for Business Students (2009, $5^{\text {th }}$ edition, FT Prentice Hall), which has also been translated into Chinese, Dutch and Russian. He has co-authored a range of other books including Strategic Human Resource Management (2007, FT Prentice Hall) and Dealing with Statistics: What you need to know (2008, Open University Press McGraw Hill). 


\section{Introduction}

For organizations and their employees, change is often argued to be a way of life. Text books such as Balogun and Hailey's (2008) Exploring Strategic Change emphasise the ubiquitous nature and ever increasing pace of change for organisations and those working within them. Within organisations change may relate to the strategic development of the organisation or be or more restricted in scope and operational in nature (Thornhill and Saunders, 2003). It may occur incrementally, continuously or in the form of punctuated equilibrium, periods of stability being interspersed by significant changes (Burnes, 2009). The management of strategic change has been argued invariably to create uncertainty and, where such change involves people, often to be problematic (McCalman and Paton, 1992). Where change is perceived as threatening, it is likely to meet with resistance and require careful implementation to overcome fears (Mabey and Salaman, 1995). This is helped where trusting relationships exist throughout the organisation (Hope-Hailey et al., 2010). Human resource practices can therefore play an important role in the management of such change whether it is incremental, continuous or punctuated equilibrium through the creation and maintenance of trust.

The primary focus of this chapter is to explore the nature of trust in relation to employees' treatment during strategic change. In particular the impact employees' treatment during change can have on their trust and the relative importance of the institutional and personal (calculative and relational) aspects of that trust and the are considered. Recent research has argued that organisational justice theory offers a means through which to explain and understand employees' trust reactions to change more fully (Mishra and Spreitzer, 1998; Saunders and Thornhill, 2004). Through integrating perceptions about the outcomes of organisational decisions, the processes through which they were made, and the treatment of those affected (Colquitt et al., 2005), it provides a means of exploring employees' trust reactions and their reasons for these.

In this chapter the strength of employees' self categorized feelings of trust and the relationship between these and their perceptions of treatment during organisational change is considered. Following a discussion of the nature of trust in which institutional and personal aspects are explored briefly, organisational justice is conceptualised in relation to the management of strategic change. Using a case study drawn from a United Kingdom (UK) public sector organisation undergoing incremental change following a strategic reorganisation, these trust reactions are explored using organisational justice as an explanatory theory. The chapter concludes with a discussion regarding the nature of trust and the implications of this for the management of human resources during strategic change. As part of this the limitations of this study and directions for future research are reflected upon.

\section{Trust, justice and change}

\section{Trust}

The development of trust theory has, to date, focused on a range of levels of analysis from the personal to the institutional (Rousseau et al., 1998), reviewed in some detail by Bigley and Pearce (1998). Although these conceptualisations have resulted in a variety of definitions of trust, over the past decade agreement has begun to emerge regarding a composite definition. This incorporates the notions of favourable or positive expectations (Lewicki and Bunker, 1996) and a willingness to make oneself vulnerable to others (Mayer et al., 1995). One of the most widely cited definitions reflecting these components, and that adopted for this chapter is "...a psychological 
state comprising the intention to accept vulnerability based upon positive expectations of the intentions or behaviour of another" (Rousseau et al., 1998: 395). Perceived motives and intentions therefore influence how individuals evaluate their levels of trust with associated implications for workplace cooperation and for team work (Jones and George, 1998). Consequently, others' behaviours are an integral part of an individual's decision to trust, enabling learning about intentions through observation and interpretation. Based upon such behaviours, individuals make judgements about and act upon the perceived trustworthiness of others. Such judgements are, in turn, expressed and manifest in their own behaviours.

Where behaviours inform trust in individuals such as a line manager or members of a work group, trust is likely to develop over time. Initially such personal trust will be based upon rational choice, perceived positive intentions being derived from credible information from others rather than personal experience. This is known as calculus based trust (Rousseau et al., 1998). Repeated positive experiences will, over time, build upon the initial calculus based trust to create high levels of relational trust as individuals come to know each other. Within such relationships, emotional responses are important as attachments are formed based upon reciprocated care and concern (McAllister, 1995).

Inevitably personal trust will be influenced by the organisational frameworks within which it operates (Weibel, 2003). These are likely to include the human resource management processes and procedures of the organisation, including those related to change, and the way they function, formal and informal rules that protect the rights of employees and the organisations culture (Rousseau et al., 1998). Such institutional controls also allow trust to be extended beyond those known personally to organisations or larger groups within them, informing individuals' institutional trust at the organisational level. These forms of trust together represent the diversity of trust in organizational settings.

\section{Organisational justice and strategic change}

Organisational justice theory offers a means to conceptualise employees' trust in relation to the outcomes of change and with regard to the human resource interventions used to achieve these outcomes and the management of those affected. Focussing on judgements about perceived fairness, organisational justice can be considered to have close parallels with trust where expectations are based upon perceptions of treatment and perceived motives (Saunders and Thornhill, 2004). It therefore offers a means to understand the relationship between employees' personal and institutional trust and the nature of their treatment within a context of strategic change.

A series of constructs have been identified for organizational justice theory within the literature (Greenberg and Colquitt, 2005). The first of these relates to employees' perceptions about the outcomes of decisions and is labelled distributive justice (Homans, 1961). Perceptions about the processes used to arrive at, and to implement, these decisions form the basis of two further constructs, which are treated as one in some literature: procedural justice and interactional justice. Procedural justice focuses on employee perceptions of fairness of procedures used to make decisions (Thibaut and Walker, 1975). This has been distinguished from interactional justice which focuses on employees' perceptions regarding fairness of interpersonal treatment received during implementation (Bies and Moag, 1986). Initially Bies and Moag (1986) it was suggested this consisted of two distinct constructs: treatment of people (interpersonal justice) and the explanations with which these people were provided (informational justice). Subsequently, this was 
disputed on the basis that interactional justice produced the same perceptual outcomes as procedural justice (Cropanzano and Greenberg, 1997). More recently it has been argued that procedural, informational and interactional justice are empirically distinct (Kernan and Hanges, 2002). The separation of organisational justice into these four constructs allows for the possibility of differential impacts on trust, which are now considered.

\section{Outcome fairness}

Distributive justice refers to employees' perceptions about the fairness of outcomes that affect them. These will be based on a subjective judgement about her or his treatment in relation to effort and investments, as well as the relative treatment of others (Adams, 1965) such as co-workers. In relation to organisational change, such comparisons may take into account subjectively formed judgements about what is happening to the organisation in general. These judgements are therefore likely to be multifaceted, based on broad and generalised perceptions about what is happening to the organisation at a number of levels (Novelli et al., 1995) and varying according to circumstances and situations. Overall feelings of trust are therefore likely to be affected by comparisons to the relative treatment and outcomes of others, alongside comparisons regarding more generalised opportunities such as those available within a trustor's occupational group, organisation or another organisational context (Saunders and Thornhill, 2004), involving both institutional and personal components.

\section{Process fairness}

The importance of procedural justice for many aspects of human resource management has been recognised (Folger and Cropanzano, 1998) along with associated trust (Lewicki et al., 2005). Genuinely fair procedures and processes have been found to moderate the impact of negative reactions arising from decisions leading to undesirable employee outcomes (Brockner and Siegel, 1996). Such perceptions are considered to have a greater impact than those related to distributive justice because, whereas outcomes are viewed as happening only once, procedures have a more enduring quality (Pillai et al., 2001; Tyler, 1994). This arises where the positive effects of a fairly perceived procedure help to moderate negative reactions that would otherwise arise from an adverse organisational outcome (Brockner and Greenberg, 1990). Research to understand the dynamics of procedural justice has focused on the concepts of voice and process control. Voice allows those affected to exercise some degree of process control, or personal influence, in relation to the process of reaching a decision (Thibaut and Walker, 1975; Greenberg and Folger, 1983). This ability has been linked to a number of positive reactions (Mishra, 1996) not least personal trust.

The conceptual distinction between procedural and distributive justice may be blurred where employees are unable to influence decision making procedures or exercise any level of control in relation to outcomes (Folger and Cropanzano, 1998). This likely to be the case in relation to many corporate decisions, such as those relating to strategic change where, in reality, employees have limited voice in the process. In such cases however employees will still form perceptions about the decisions made and procedures used, even where they have exercised little or no direct influence in the process. In this context there is a need to differentiate between the structural nature of procedural justice (and the associated implications for institutional trust), the accuracy and quality of subsequent information received and interpersonal treatment arising from the implementation. These are discussed in the following sub section. 


\section{Informational and interpersonal fairness}

Opportunities for process control are also likely to occur as part of interactions during the implementation of change. The stage at which decisions are implemented is associated with informational and interpersonal justice. These forms of justice are likely to be particularly significant where employees exercise a low level of control in relation to both decisions made and the procedures used to make them. In such circumstances, senior management and line managers in particular can significantly influence the way other employees react to the implementation of change.

Informational justice is related to communications, in particular from senior managers (Saunders and Thornhill, 2003), with facets of this justice construct focussing upon the candid nature, thoroughness and reasonableness of explanations given, their timeliness and the extent to which they are tailored to individuals' specific needs. Research has indicated that employees are more likely to accept decisions, even if unfavourable, when given adequate and genuine reasons (Daly and Geyer, 1994). This highlights the role that communication may play in engendering, in particular, institutional trust during change, influencing the willingness to become vulnerable (Saunders and Thornhill, 2004).

In contrast, interpersonal justice focuses upon the extent to which the implications of decisions are recognised by more immediate managers and explained to employees sensitively with consideration (Moorman, 1991) as well as their treatment (Colquitt, 2001). The way in which employees are treated is therefore likely to impact on their perceptions about fairness in relation to the process of implementation in general and the moral obligation to treat everyone fairly. This has been found to relate to employees' trust in management (Kernan and Hanges, 2002, Mayer et al., 1995). suggesting a clear role for way in which employees are managed during change in the development of their perceptions of fairness and the generation of personal trust.

\section{Data collection}

To explore trust within the context of employees reactions to strategic change research was conducted in 2008 from a public sector organisation that we refer to as "Shirecounty". Shirecounty had come into existence on $1^{\text {st }}$ April 1998, as part of the local government reorganisation in England and Wales, being responsible for provision of education, caring services, police, traffic, road building and maintenance, libraries and strategic planning. Over the next eight years Shirecounty instituted major changes as part of an improvement process, the UK Government's Audit Commission $(2005,2007)$ recognising this continual improvement and categorising the Council as 'good' in its comprehensive performance assessments for 2002 and 2003, 'excellent' in 2004 and 'performing strongly' in 2005 and 2006.

In 2006, in response to the Children Act 2004, Shirecounty restructured, the principle change being the separation of services for children and adults. Throughout the transformational change process formal communication channels such as a weekly newsletter and team briefings were used to keep employees informed of the progress. Although the need for new organisational structures had created uncertainty, Shirecounty's senior management perceived there was little resistance to change and that it had been managed well.

For the period subsequent to the 2006 restructuring until the time of data collection, the UK Government's Audit Commission (2009) recognised continuing improvement continuing to assess the Council as 'performing strongly'. Shirecounty made further incremental changes including revising corporate performance management support 
systems and procedures, introducing flexible working and appointing a new Chief Executive. Although some changes were fine tuning (Dunphy and Stace, 1993) in response to issues raised by the transformational change, others were in response to new initiatives from central government.

Data collection consisted of a structured card sort of possible responses to change (derived from Saunders et al., 2004) and a subsequent audio recorded in-depth interview to explore and explain each respondent's categorisation of responses and interpretation of the associated contexts. These data were obtained from a random sample of 27 employees in post for at least one year stratified according to level within the organisation's hierarchy including administrative and technician employees (13), professionals and middle managers (12) and senior managers (2); the sample being drawn from across Shirecounty's six new directorates: Environmental Services (7), Corporate Services (5), Financial Services (2), Adult and Community Services (4), Children and Family Services (excluding those based in schools) (7) and Planning and Economic Performance (2).

The card sort involved each participant sorting 50 cards that expressed a possible response in the active voice; for example 'sceptical' rather than "scepticism". Responses included 'trusting' and 'distrustful', 13 expressions and manifestations of trust and distrust identified by Lewicki et al. $(1998)^{1}$ and 35 emotions identified and used by Saunders and Thornhill $(2004)^{2}$ and derived from literatures relating to psychology and stress. At the start of the card sort each participant was informed that the purpose of the research was to establish and understand her or his 'feelings in relation to the managed change at Shirecounty', it being stressed there were no wrong answers. Employees were asked to categorise each possible response as either 'do not feel' or 'feel to some extent'. Those responses categorised as 'do not feel' were removed and recorded, following completion of this initial sort. In two further sorts of the remaining cards participants selected those which they feel strongly and subsequently the three about which they felt most strongly.

The card sort was followed immediately by a one hour interview focussing upon each participant's categorisation of these possible responses, commencing with those felt most strongly. Within each interview, the selection and relative position of each employee's feeling of 'trusting' was introduced using the question '...l've notice that you categorised... ... can we talk about this?' Participants were encouraged to discuss and explain their response in the context of their own perceptions of the changes. This allowed their trust reactions to be described and explored from a grounded and subjective perspective.

The interview transcripts were used to make sense of relationships between trust and how employees were managed within the context of participants' interpretations of the organisational change. Following Saunders and Thornhill (2004), each paragraph of the interview relating to the three most strongly felt responses was categorized according to whether that participant appeared to interpret change as favourable, unfavourable, mixed (having both favourable and unfavourable aspects).

\footnotetext{
${ }^{1}$ The six expressions were: confident, cynical, faithful, fearful, hopeful and sceptical. The seven manifestations were: assured, hesitant, low monitoring, passive, take the initiative, vigilant and wary and watchful.

2 The 35 emotions were: angry, calm, cheerful, comfortable, concerned, confused, demoralised, depressed, determined, disinterested, eager, enthusiastic, excited, expectant, frustrated, in control, indifferent, insecure, involved, keen, on edge, optimistic, overwhelmed, panicky, positive, powerless, relaxed, relieved, resentful, resigned, secure, stressed, under pressure, vulnerable, worried.
} 
Subsequently each paragraph of the interview relating to trust was categorized according to whether the respondent referred to institutional or personal trust or both. This allowed the nature of respondents trust to be explored in relation to the overall strength of their trust. The four dimensions of organisational justice theory were introduced subsequently to explore and make sense of the relationships between the strength of trust feelings and personal and institutional trust, each sentence being coded regarding the presence of distributive, procedural, informational and interpersonal justice. In doing this the analysis was developed in a way that was grounded in the respondents' data.

\section{Employees' feelings of trust and reactions to change}

The card sort revealed that all but two of these participants were trusting at least to some extent in relation to the incremental change (Table 1). Subsequent consideration of the explanations given by employees for their most strongly felt responses highlighted that the majority (67 percent) felt favourably about the changes focussing entirely upon these aspects when justifying their choices. A further 30 percent focussed on both favourable and unfavourable aspects, only one participant focussing entirely upon unfavourable aspects.

\section{Ideal place for Table 1}

Explanations from the 16 employees who focussed entirely upon favourable aspects when explaining their most strongly felt responses suggested a sense of involvement and, to a lesser extent wellbeing. Responses such as 'enthusiastic' (6), 'involved' (4) and 'take the initiative' (3) were explained by highlighting their feelings of involvement in the change, albeit without being able to influence the process. A typical comment from a professional employee in relation to 'enthusiastic' being: "I think that what we are doing here, with my area of working particularly, is very exciting and has very big potentials to make a difference to children's lives." An administrative assistant commented "I've only been here three years and it was a new job for me... ... It's a new job and I'm quite enthusiastic." Comments made in relation to responses such as 'comfortable' (4), 'hopeful' (3), 'faithful' (3), 'optimistic' (3), 'positive' (3) also highlighted a sense of well-being amongst these employees, for example another administrator justifying her choice of comfortable in relation to perceived outcome fairness in other organisations "Because I think the County Council is such a big organisation and I think they do things better than probably a lot of comparable organisations of their size."

Eight employees who focussed on favourable aspects of the changes felt trusting to at least some extent, a further six felt strongly trusting and two selected trusting as one of their three most strongly felt responses. The reasons given for responses selected by those who felt strongly trusting focussed primarily on their sense of wellbeing in relation to the changes, in particular their treatment by immediate colleagues. An administrator who felt 'comfortable' explained "I feel comfortable with my colleagues, you know, we can talk about things" whilst a professional employee commented "I like the atmosphere here. It is nicer than where I worked before... there seems to be more support here." In contrast, those who only felt trusting to some extent also referred to change outcomes, in particular how work had altered. A manager justified his choice of 'under pressure' "I think it is just the nature of the job and the way it has changed, there did not used to be the pressure. I suppose because you know there were times when it seemed to be quieter and it is the nature of the beast I think, you know it has changed." whilst a professional employee commented "...I think we are all under pressure aren't we so you see I don't see that necessarily as a bad thing in some ways... I think we should be under pressure just 
to get it right. But, at the same time, sometimes expectations are a little bit unrealistic, you know."

In contrast, the eight employees who focussed on both favourable and unfavourable aspects of change selected responses that highlighted that they were 'frustrated' (4), as well as 'under pressure' (3) in relation to the changes. Their responses referred to both the outcomes of the restructuring and of subsequent incremental changes. A middle manager explained her selection of 'frustrated': "I was talking about me and my staff not being in the same place, for example, and I am very frustrated at the impact of our better systems, better services initiative which I personally feel has been an unmitigated disaster" emphasising outcomes of restructuring she perceived as negative. Conversely, an administrative staff member who had previously worked in the private sector was 'frustrated' regarding the pace of change justifying his choice of that response: "'Frustrated', now I am frustrated because things don't start quickly enough".

Responses of those employees who discussed on both favourable and unfavourable aspects of change differed depending upon the strength of trust feelings. The four who felt strongly trusting emphasised a sense of wellbeing whilst, in some cases, still feeling vulnerable and frustrated. For these employees, strong trust appeared to be linked to positive relationships with both their immediate colleagues and their line manager. In contrast those employees who were trusting only to some extent appeared to be less certain regarding there own well-being, feeling concerned and under pressure. Whereas frustration for those who were strongly trusting was focussed upon not being able to do as good a job as they would have wished due existing processes and procedures or lack of funding, for those who were trusting to some extent, it was related to their treatment. An administrator who was only trusting to some extent, commented about her frustration "I get like told off for it [by my manager] because that is not my job, that is the important worker's job even though they are not around and the information is needed... You know, you shouldn't use your initiative." In contrast an administrator who felt strongly trusting who selected 'frustrated' commented "I am frustrated because I would like to progress within the organisation, like progress with my career and so forth, but I have not really been successful with that so far" and, whilst noting that support was available from Shirecounty, "...there are sort of opportunities and I think the County Council is very good at supporting you with training". The nature of this trust and its interrelationship with organisational justice is now considered.

\section{The nature of trust and just treatment}

Analysis of in depth interview data enabled feelings of trust to be categorized in terms of their discussion of institutional, personal or both institutional and personal aspects (disregarding the two participants who did not feel trusting). The largest of these groups, trusting to some extent considering only personal trust aspects, consisted of eight participants (32 per cent). In contrast, only four participants (16 per cent) who felt trusting to some extent considered just institutional trust aspects in their justification. Four participants (16 per cent) who felt strongly trusting considered only institutional aspects of trust in their justification, whilst the eight participants (32 percent) who felt either strongly trusting or had selected trusting as one of their most strongly felt reactions considered both institutional and personal aspects of trust in their justification (Table 2). Statistical analysis of these data reveals a significant ${ }^{3}$

\footnotetext{
${ }^{3}$ Data were cast into a two by two table consisting of 'feeling trusting to some extent' or 'strongly/most strongly' and 'personal or institutional trust' or 'both personal and institutional trust'. Analysis resulted in $\chi^{2}=9.24, p<0.01$, d.f. $=1$.
} 
association between the strength of trust feelings and the aspect(s) of trust considered.

\section{Ideal place for Table 2}

Participants who were trusting to some extent were more likely to consider aspects of either personal trust or, to a lesser extent, institutional trust in their justification for this level of trust. In contrast, participants who felt either strongly trusting or selected trusting as one of the three they reactions they felt most strongly tended to consider both institutional and personal aspects of trust or, in a third of cases, just personal aspects of trust. Thus, whilst personal trust predominated in the justification for the strengths of trust feelings, for those participants whose trust feelings were strong; this was usually combined with institutional trust. The reasons given for these associations are now considered.

\section{Trusting to some extent}

Participants who felt trusting to some extent justified this in terms principally of either interpersonal, procedural and to a lesser extent informational justice of the incremental changes that were occurring at Shirecounty. Within this, whether participants considered personal trust, institutional trust or both personal and institutional trust; interpersonal aspects of their treatment were, without exception, reported positively. These interpersonal aspects were used by participants to justify feelings of being trusting to some extent, the focus of this being personal relationships they had developed with work colleagues and their immediate managers.

The eight participants, who focussed upon personal trust in their justification of why they felt trusting to some extent, often appeared to be circumspect about the quality of information they received about changes as well as some of the processes and associated outcomes. For these participants, aspects of their interpersonal treatment appeared to have mitigated negative aspects of the change, being in part related to "a people friendly approach" that was contrasted by some with "a sort of ruthless, cutthroat" private sector. This occurred at all levels. An administrative employee highlighted how, despite a promotion panel's outcome being in his opinion unjust, his manager had supported his application for training and helped ensure it was successful. Similarly, a manager who explained his feeling: “...a bit of trusting... I think part of what comes from that is that I feel I have some degree of relationship with the senior managers who are, I suppose in charge of my destiny..." This manager commented negatively upon the general process of change and the associated outcomes "If the 'better systems, better services' initiative had saved absolutely packets of money which was then being diverted into helping vulnerable families, then I would have been $100 \%$ behind it, no office or no office." Another manager, focussed on her inability to influence the change process: "I suppose it is feeling absolutely sure that something is going to happen and it doesn't. I hate the politics of it all, I do. ...they say 'yea, yea we have listened to you and we are going to stop doing that' and you just know they are going to do it round the corner."

In contrast the four participants who focussed upon institutional trust in justifying their feeling trusting to some extent, emphasised the policies and procedures used by the organisation. These participants' feelings of trust did not appear to be based upon their own interpersonal treatment. Managers in this group referred to "the open door policy", one stating "I know I can go as high as necessary to talk about it, to get it sorted". In contrast administrative employees referred to employees being "watched" 
and "reviewed" one female commenting "I tend to find that people who aren't doing their jobs properly are the ones that get watched and get pulled in more."

\section{Strongly trusting}

All 12 participants who felt at least strongly trusting in relation to the changes highlighted their personal trust, two thirds (eight) also discussing institutional trust. No participants who felt strongly trusting highlighted only institutional trust when justifying their feelings. For those employees who highlighted both personal and institutional trust, this was discussed in relation to the just nature of the interpersonal treatment by seven of the eight participants. Procedural justice was discussed by six participants, the distributive and informational justness of the treatment received being discussed by three and two participants respectively. In contrast, the four employees who focussed only upon personal trust discussed this primarily in relation to information they received, only one employee also considering other aspects of justice.

Those participants, who discussed aspects of both institutional and personal trust in relation to the change, felt both their interpersonal treatment and the procedures used by Shirecounty were fair. This was typified, in relation to procedures, by an administrator who commented "Nothing appears to be hidden. There is [sic] no hidden agendas." Similarly, a professional employee commented "I certainly feel that the connections I have with the County Council are trusting in both directions... It's, you know, the County Council has done a lot of work to set up this partnership and is demonstrating its support for it." The justness of interpersonal treatment was discussed in terms of their relationship with work colleagues and their immediate line manager. For one administrative employee this was explained: "I think they [Shirecounty] are a good organisation to work for... My team as well, my manager, you know I feel like I get on well with them, there is no sort of back-stabbing, nastiness or anything. It is a nice environment." emphasising the importance of fair interpersonal treatment from both their line manager and work colleagues. For another, it was summarised as "If you have something to talk over, a minor problem or whatever, I have always found they have time to listen."

Distributional and informational justice aspects of treatment were commented upon less widely, the former usually being discussed in terms of the outcomes of recruitment both for the employee and for the organisation in general. In contrast informational justice related to the explanations given to individuals regarding their own treatment as part of the change and associated decisions. However, unlike for those employees who were only trusting to some extent, the explanations were considered just and believed. A middle manager stated "They might use things to their advantage perhaps at times, and to skew it slightly, but I don't think they deliberately go about trying to pull the wool over the eyes of staff. I do trust what they are saying."

Participants who were at least strongly trusting, but just discussed personal trust, considered only interpersonal justice in their discussion. These four participants, like the majority of others highlighted their work group, a female administrator commenting "I would definitely trust my line manager and that whatever I told her would, you know, remain confidential whatever". A male administrator also related such trust in his workgroup to the outcomes "...you know you can be fairly sure if you ask somebody to do something or somebody says that they will do something, then you know, unless something happens that is totally out of their power, then they will do it." 


\section{Discussion}

This chapter commenced with the stated purpose of exploring the nature of trust as one of a number of employees' reactions to their treatment in relation to change. Drawing upon a case study of a UK public sector organisation, which was performing well and in which change was perceived to have been responded to favourably, employees' reactions 'were considered in relation to the strength of their trust feelings.

Employees who felt trusting at least to some extent focussed predominantly on positive aspects when talking about their reactions to the change. These employees highlighted their enthusiasm for and sense of involvement in the change as well as a sense of wellbeing, in particular with regard to positive working relationships with their colleagues and their line managers, emphasising the importance of interpersonal aspects. Where there were negative feelings for those who felt strongly trusting, these related to them not being able to do as good a job as they would have wished due changed processes and procedures or a lack of funding rather than the way in which the change was being managed. In contrast, negative feelings of employees who felt trusting to some extent appeared to be due to their personal treatment during the change or the negative impact of human resource decisions. For these employees interpersonal treatment appeared to have mitigated against negative effects of other aspects of the change process in regard to trust. This was particularly apparent where employees considered an aspect of the process or certain of outcomes were unjust.

Subsequent consideration of the overall levels of trust in relation to the focus or foci of trust highlighted that employees who felt strongly trusting in relation to organisational change were likely to consider both institutional and personal aspects of trust in justifying their feelings. In contrast, employees who only felt trusting to some extent considered only personal or institutional aspects of trust when justifying their feelings. This emphasises the importance of paying attention to factors that impact on personal trust and on institutional trust when managing change.

For Human Resource Managers seeking to engender trust in employees during ongoing incremental change this research has two key implications. Firstly, it emphasises the importance of line managers and work colleagues being sensitive to individuals needs during the implementation of change, whatever their level in the organisation to help engender trust. This sensitivity and the associated interpersonal treatment has been shown to mitigate against negative effects upon trust such as outcomes from the change which are considered unfavourable as well as processes that are considered unjust. Secondly the research highlights how the wider organisational environment and in particular the associated human resource management practices impact upon both institutional trust reactions and the overall level of trust. In particular, where employees feel trusting at an organisational level as well as a personal level, their overall strength of trust feeling is likely to be significantly higher.

Despite these findings, it needs to be recognised that these conclusions are based upon a single case study of 27 respondents where incremental change was perceived as being implemented successfully. This highlights the scope for further empirical research to explore further and test these relationships in different settings such as where change is not perceived as being implemented successfully or in other sectors.

\section{References}


Adams, J.S. (1965). Inequity in Social Exchange in Berkowitz L., (ed.) Advances in Experimental Social Psychology, Vol. 2, Academic Press, New York, pp. 267 - 299.

Audit Commission (2005) Comprehensive Performance Assessment: Scores and analysis of performance in single tier and county councils 2004 London: Audit Commission [Accessed 12 October 2009] Available at: http://www.auditcommission.gov.uk/SiteCollectionDocuments/InspectionOutput/CPAscores2004.pdf

Audit Commission (2007) CPA - The Harder Test: Scores and analysis of performance in single tier and county councils 2006 London: Audit Commission [Accessed 12 October 2009] Available at: http://www.auditcommission.gov.uk/SiteCollectionDocuments/InspectionOutput/CPATheHarderTest2 006.pdf

Audit Commission (2009) CPA - The Harder Test: Scores and analysis of performance in single tier and county councils 2008 London: Audit Commission [Accessed 12 October 2009] Available at: http://www.audit-

commission.gov.uk/SiteCollectionDocuments/AnnualReports/2009/05032009CPATh eHarderTestREP.pdf

Balogun J and Hope Hailey V (2008) Exploring Strategic Change ( $3^{\text {rd }}$ edn.) Harlow: FT Prentice Hall.

Bies, R.J. and Moag, J., (1986). Interactional justice: Communication criteria of fairness in R Lewicki, B Sheppard and M Bazerman (Eds.) Research on Negotiation in Organizations Vol. 1, JAI Press, Greenwich, CT. 43-55

Bigley, G.A. and Pearce, J.L. (1998). 'Straining for Shared Meaning in Organisational Science: Problems of Trust and Distrust', Academy of Management Review 23.3, 405-21.

Brockner, J. and Greenberg, J. (1990). 'The Impact of Layoffs on Survivors: An Organizational Justice Perspective'. In J.S. Carroll (Ed.), Applied Social Psychology and Organizational Settings, Hillsdale, N.J: Erlbaum. 45-75.

Brockner, J. and Siegel, P. (1996). 'Understanding the Interaction Between Procedural and Distributive Justice: the Role of Trust'. In R.M. Kramer and T. Tyler (Eds.), Trust in Organisations, (pp. 390-413). Thousand Oaks, CA: Sage.

Burnes B (2009) Managing Change ( $5^{\text {th }}$ edn.) Harlow: FT Prentice Hall.

Colquitt, J.A. (2001). 'On the Dimensionality of Organizational Justice: A Construct Validation of a Measure' Journal of Applied Psychology, 86, 386-400.

Colquitt JA, Greenberg J and Zapata-Phelan (2005) What is Organizational Justice? A Historical Overview. In J Greenberg and JA Colquitt Handbook of Organizational Justice Mahwah, NJ, Lawrence Erlbaum Associates 3-58.

Cropanzano, R. and Greenberg, J. (1997). Progress in Organizational Justice: Tunnelling Through The Maze in CL Cooper and IT Robertson (Eds.) International Review of Industrial and Organizational Psychology, Volume 12, Wiley, Chichester. Reprinted in CL Cooper and IT Robertson (Eds.) (2001). Organisational Psychology and Development, Wiley, Chichester, pp. 243-298. 
Daly, J.P. and Geyer, P.D. (1994). 'The Role of Fairness in Implementing LargeScale Change: Employee Evaluations of Process and Outcome in Seven Facility Relocations', Journal of Organizational Behaviour, 15, 623-638.

Dunphy, D. and Stace, D. (1993). The strategic management of corporate change, Human Relations 45. 8, 905 - 920.

Folger, R. and Cropanzano, R., (1998). Organizational Justice and Human Resource Management, Thousand Oaks, CA, Sage.

Greenberg J and Colquitt JA (2005) Handbook of Organizational Justice Mahwah, NJ, Lawrence Erlbaum Associates

Greenberg, J. and Folger, R. (1983). 'Procedural Justice, Participation, and the Fair Process Effect in Groups and Organizations'. In P.B. Paulus (Ed.), Basic Group Processes, (pp. 235-256). New York: Spinger-Verlag.

Homans, G.C., (1961). Social Behavior: Its Elementary Forms Harcourt Brace Jovanovich, New York.

Hope-Hailey V, Farndale E and Kelliher C (2010, forthcoming) Trust in turbulent times: organizational change and the consequences for intra-organizational trust. In MNK Saunders, D Skinner, N Gillespie, G Dietz and R Lewicki (eds) Organizational trust: a cultural perspective Cambridge, Cambridge University Press

Jones, G.R. and George, J.M. (1998). 'The experience and evolution of trust: Implications for cooperation and teamwork', Academy of Management Review, 23.3, 531-546.

Kernan, M.C. and Hanges, P.J. (2002). 'Survivor Reactions to Reorganization: Antecedents and Consequences of Procedural, Interpersonal, and Informational Justice', Journal of Applied Psychology, 87, 916-28.

Lewicki, R.J. and Bunker, B.B. (1996). 'Developing and Maintaining Trust in Work Relationships'. In R.M. Kramer and T.R. Tyler (eds.), Trust in Organisations: Frontiers of Theory and Research. Thousand Oaks, CA: Sage. 114-39

Lewicki, R.J., McAllister, D.J. and Bies, R.J. (1998). 'Trust and distrust: New Relationships and Realities', Academy of Management Review, 23.3, 438-58

Lewicki, RJ, Wiethoff, C and Tomlinson EC (2005) What is the Role of Trust in Organizational Justice? In J Greenberg and JA Colquitt Handbook of Organizational Justice Mahwah, NJ, Lawrence Erlbaum Associates 247-272.

Mabey, C. and Salaman, G. (1995). Strategic Human Resource Management, Oxford, Blackwell.

McAllister, D. J. 1995. Affect- and cognition-based trust as foundations for interpersonal cooperation in organizations. Acaden3/ of Management Journal. 38.1 24-59.

Mayer, R.C., Davis, J.H. and Schoorman, F.D. (1995). 'An Integrative Model of Organizational Trust', Academy of Management Review, 20.3, 709-34. 
Mayer, R.C. and Davis, J.H. (1999). 'The Effect of the Performance Appraisal System on Trust for Management: a Field Quasi-Experiment', Journal of Applied Psychology, 84,123-136.

McCalman, J. and Paton, R.A. (1992). Change Management A Guide to Effective Implementation, London, Paul Chapman.

Mishra, A.K. (1996). 'Organizational Response to Crisis'. In R.M. Kramer and T.R. Tyler (Eds.), Trust in Organisations: Frontiers of Theory and Research, Thousand Oaks, CA: Sage 261-287.

Mishra AK and Spreitzer GM (1998) Explaining how survivors respond to downsizing: the roles of trust, empowerment, justice and work redesign Academy of Management Review 23.3, 567-588.

Moorman, R.H. (1991). Relationship between organizational justice and organizational citizenship behaviors: Do fairness perceptions influence employee citizenship? Journal of Applied Psychology 76, 845 - 855.

Novelli, L., Kirkman, B.L. and Shapiro, D.L. (1995) Effective implementation of organizational change: an organizational justice perspective in Cooper C.L. and Rousseau, D. (eds.) Trends in Organizational Behaviour Vol. 2, Basingstoke, Wiley 15-35.

Pillai, R., Williams, E.S. and Tan, J.J. (2001). 'Are the Scales Tipped in Favour of Procedural or Distributive Justice? An Investigation of the U.S., India, Germany and Hong Kong (China)', The International Journal of Conflict Management, 12, 312-32.

Rousseau, D.M., Sitkin, S.B. Burt, R.S. and Carmerer, C. (1998). 'Not so Different After All: a Cross-Discipline View of Trust', Academy of Management Review 23.3, 393-404.

Saunders MNK and Thornhill A (2003) Organisational justice, trust and the management of change: An exploration Personnel Review. 32.3, 360-374

Saunders MNK and Thornhill, A (2004) Trust and mistrust in organisations: An exploration using an organisational justice framework European Journal of Work and Organisational Psychology 13.4, 492-515

Thibaut, J. and Walker, L., (1975). Procedural Justice, Erlbaum, Hillsdale, N J.

Thornhill A and Saunders MNK (2003) Exploring employees' reactions to strategic change over time: The utilisation of an organisational justice perspective Irish Journal of Management. 24.1, 66-86

Tyler, T.R. (1994). Psychological models of the justice motive: Antecedents of distributive and procedural justice. Journal of Personality and Social Psychology 67, $850-863$.

Weibel, A. (2003), Book review -Trust within and between organizations by Lane and Bachmann, Personnel Review, 32.5, 667-71. 
Table 1: Most strongly felt responses to change by strength of trust

\begin{tabular}{|c|c|c|c|c|}
\hline $\begin{array}{l}\text { Explanation } \\
\text { for selection } \\
\text { of three } \\
\text { most } \\
\text { strongly felt } \\
\text { responses }\end{array}$ & Do not feel trusting & $\begin{array}{l}\text { Trusting to some } \\
\text { extent }\end{array}$ & $\begin{array}{l}\text { Strongly } \\
\text { trusting }\end{array}$ & $\begin{array}{l}\text { Trusting one } \\
\text { of } 3 \text { most } \\
\text { strongly felt }\end{array}$ \\
\hline $\begin{array}{l}\text { Focussed on } \\
\text { favourable } \\
\text { aspects of } \\
\text { change }\end{array}$ & $\begin{array}{l}\text { Determined (2) } \\
\text { Eager } \\
\text { Expectant } \\
\text { Involved } \\
\text { Take the initiative }\end{array}$ & $\begin{array}{l}\text { Enthusiastic (3) } \\
\text { Hopeful (3) } \\
\text { Under pressure (3) } \\
\text { Confident (2) } \\
\text { Faithful (2) } \\
\text { Cheerful } \\
\text { comfortable } \\
\text { Determined } \\
\text { Involved } \\
\text { Keen } \\
\text { On edge } \\
\text { Optimistic } \\
\text { Positive } \\
\text { Relieved } \\
\text { Take the initiative } \\
\text { Vigilant }\end{array}$ & $\begin{array}{l}\text { Comfortable (3) } \\
\text { Involved (3) } \\
\text { Enthusiastic (2) } \\
\text { Optimistic (2) } \\
\text { Positive (2) } \\
\text { Excited } \\
\text { Faithful } \\
\text { In control } \\
\text { Low monitoring } \\
\text { Relaxed } \\
\text { Take the initiative }\end{array}$ & $\begin{array}{l}\text { Trusting (2) } \\
\text { Determine } \\
\text { Enthusiastic } \\
\text { Take the initiative } \\
\text { Under pressure }\end{array}$ \\
\hline $\begin{array}{l}\text { Focussed on } \\
\text { both } \\
\text { favourable } \\
\text { and } \\
\text { unfavourable } \\
\text { aspects of } \\
\text { change }\end{array}$ & & $\begin{array}{l}\text { Concerned (2) } \\
\text { Frustrated (2) } \\
\text { Under pressure (2) } \\
\text { Determined } \\
\text { Faithful } \\
\text { Keen } \\
\text { Positive } \\
\text { Stressed } \\
\text { Wary and watchful }\end{array}$ & $\begin{array}{l}\text { Enthusiastic (2) } \\
\text { Frustrated (2) } \\
\text { vulnerable (2) } \\
\text { Confident } \\
\text { Expectant } \\
\text { Involved } \\
\text { Positive } \\
\text { Secure } \\
\text { under pressure }\end{array}$ & \\
\hline $\begin{array}{l}\text { Focussed on } \\
\text { unfavourable } \\
\text { aspects of } \\
\text { change }\end{array}$ & & $\begin{array}{l}\text { Confused } \\
\text { Frustrated } \\
\text { stressed }\end{array}$ & & \\
\hline
\end{tabular}

Table 2: Nature of trust by strength of trust

\begin{tabular}{|l|r|r|l|}
\hline Nature of trust & $\begin{array}{l}\text { Trusting } \\
\text { to some } \\
\text { extent }\end{array}$ & $\begin{array}{l}\text { Strongly } \\
\text { trusting }\end{array}$ & $\begin{array}{l}\text { Trusting one } \\
\text { of 3 most } \\
\text { strongly felt }\end{array}$ \\
\hline Institutional & 4 & & \\
\hline Personal & 8 & 4 & \\
\hline Institutional and Personal & 1 & 6 & 2 \\
\hline
\end{tabular}

